\title{
Analysis of Girder PCU Subcontractor Selection Method with Analytical Network Process (ANP) (Case Study: Musi IV Bridge Project)
}

\author{
Widi Hartono ${ }^{1}$, Dewi Handayani ${ }^{2}$, Rizky Agung Prabowo ${ }^{3}$, Yoga Kusuma Dewa ${ }^{4}$, \\ Susetyo Rohadi ${ }^{5}$ \\ \{wieds_ts@ft.uns.ac.id ${ }^{1}$,dewi@ft.uns.ac.id ${ }^{2}$,rizkiigung@gmail.com ${ }^{3}$ \} \\ Civil Engineering Department, Sebelas Maret University, Surakarta, Indonesia ${ }^{1234}$, \\ Head of Construction Division 2, Infrastructure Department 1 PT Adhi Karya (Persero), Tbk., \\ Palembang, Indonesia ${ }^{5}$
}

\begin{abstract}
Abstrak. Finding capable and reliable sub-contractors is the ideal for the main contractor in completing the project. The project performance of the winning contractor often disappoints the main contractor, indicated by the delay in work, the non-completion of the work, or the quality of work that is below the established standards. To overcome this problem, a sub-contractor selection model is made with various criteria that can be used as a basis for determining the winner with Analytic Network Process (ANP). This study uses 8 criteria divided into 2 clusters. The result is the bid price $(0.2713)$ has the biggest score. Other criteria that have a high score are administration $(0.2508)$, technical ability $(0.1073)$ and financial ability (0.0992). This shows that not only the bid price factor is the basis for determining the prospective tender winner, but there are other criteria that serve as the basis for determining prospective tender winner.
\end{abstract}

Keywords: analytical network process (ANP), sub-contractor, tender, bid price.

\section{Introduction}

PT X Is one of the state-owned contractors that has a very wide scope of work. Starting projects in Indonesia to reach countries in Asia. One of the problems often encountered by PT $\mathrm{X}$ is a sub-contractor performance problem. Some sub-contractors from the results of the assessment have poor performance, for example, the results of the work are not in accordance with the standards set or carry out a bad job. Determining the winner based on the lowest price can save project expenses. PT X has a procedure for determining the latest sub-contractors that allows reviewing the selection criteria. The main criteria used in the most recent selection so far are the lowest bid prices. The lowest price offer causes risk when the work is carried out and causes problems as above.

By carrying out a more comprehensive study of the criteria in selecting a sub-contractor, it is expected to reduce the risks that will arise. The final consideration used to select subcontractors is based on several criteria that are the main issues in the selection of subcontractors. This is expected to improve and improve the selection system for sub-contractors in PT X Risks that often occur when choosing a sub-contractor with the lowest price are adopted into the sub-contractor selection criteria. So that the selection of sub-contractors based on the

ICCSET 2018, October 25-26, Kudus, Indonesia

Copyright (C) 2018 EAI

DOI 10.4108/eai.24-10-2018.2280502 
lowest price can be backed up with other criteria that become considerations that strengthen or weaken the results of the selection of sub-contractors and are expected to get a capable subcontractor.

The sub-contractor selection model in this paper uses ANP (Analytical Network Process) by reviewing several criteria to obtain a selection model that is expected to reduce the risk of sub-contractor performance.

This study has similarities in the topics discussed, namely the selection of sub-contractors examined by [1], [2], [3], [4] and [5]. Research conducted by the author has in common the method of research conducted by Michael Almeida (2017) and [5], namely using the Analytical Network Process (ANP) method. What distinguishes this research from previous research is the relationship between the criteria used in the selection, sub-contractors.

\section{Literature References}

Based on literature reviewed in previous studies, in research conducted by [6], [1], [2], [3] and [4] using the Analytical Hierarchy Process (AHP) method. While in the research conducted by [7] and [5], the method used is the Analytical Network Process (ANP) method.

In a previous study, the object of research reviewed in general elections was divided into two, namely there was research that reviewed the selection of contractors and there was research that reviewed the selection of sub-contractors. In the research conducted by [6] and [7] review based on the selection of contractors. And in the research conducted by [1], [2], [3], and [5] review based on the selection of sub-contractors.

In the study conducted by [1], [2], [3], [4], [5], use the same criteria in the selection of subcontractors, namely financial, technical and managerial criteria. In research conducted by [1], obtained the weight of the financial criteria that is equal to (0.282), the weight of the technical criteria is equal to (0.177), and the weight of the managerial criteria is equal to $(0.167)$. In the research conducted by [2], we found the financial criteria weighting that is equal to (0.2472), the weight of the technical criteria is equal to (0.0299), and the weight of the managerial criteria is equal to (0.0577). In research conducted by [3], obtained the financial criteria weighting that is equal to $(0.30)$, the weight of the technical criteria is equal to $(0.20)$, and the weight of the managerial criteria is equal to $(0.24)$. In the research conducted by [5], we found that the financial criteria weighting was $(0.40)$, the technical criteria weighting was $(0.26)$, and the weight of managerial criteria was (0.18).

Based on the weighting criteria above, in a study conducted by [1], [3], and [5] criteria that are a priority in the selection of sub-contractors are financial criteria. Whereas in the research conducted by [2], financial criteria are not a priority criterion in the selection of sub-contractors but rather criteria of quality with a weight of $(0.2557)$.

\section{Methodology}

The Musi IV Bridge Project is administratively located in Kuto Batu Village and Lawang Kidul Village in Seberang Ilir, while in Seberang Ulu is located on Ahmad Yani Street in 14 Ulu Village, Seberang Ulu II Subdistrict, Palembang, South Sumatra.

Primary data was obtained from interviews and questionnaires on respondents consisting of experienced PT X employees and respondents from academics and practitioners outside PT 
$\mathrm{X}$ Secondary data used is guidelines for procurement of goods and services and recap of subcontractor assessments from PT X and profile data from sub-contractor companies that bid for sub-works in Palembang's Musi IV Bridge project.

\section{Discussion}

\subsection{Identification of criteria}

The criteria identification process begins by determining the criteria used in the selection of subcontractors. Criteria are determined by conducting interviews with the project manager and literature studies from previous research journals. From the identification process, the criteria used in the selection of sub-contractors were obtained:

a. Financial Capability (FC)

These financial capability criteria include the financial condition of the sub-contractor, and how much the strength of the company's working capital.

b. Technical Capability (TC)

The criteria for this technical capability include the basic technical capabilities of the sub-contractor, as well as the experience and understanding of the requirements for implementing the project.

c. Previous Experience (PE)

This previous experience criterion includes the experience and number of projects that have been carried out by sub-contractors.

d. Resource (RS)

The criteria for this resource include the quality of resources owned by sub-contractors, including human resources, materials and equipment.

e. HSE (Health, Safety, Security and Environment) (HS)

These health, safety, security and environmental criteria include the potential risks that are prioritized by the sub-contractor for the safety of the work carried out.

f. Current Workload (CW)

The criteria for the ongoing project load include the potential risk of the project that the sub-contractor prioritizes the project being worked on.

g. Administration (AD)

This administrative criterion includes the completeness of the sub-contractor administrative documents relating to the requirements in the tender.

h. Bid price (BP)

The criteria for this bid price include how much the bid value submitted by the subcontractor with specifications in accordance with the requirements of the auction.

\subsection{Hierarchy Model}

Fig. 1 shows the model / hierarchy used in this study based on the groups that have been created and the interdependence relationship between criteria. Criteria are grouped into 2 clusters, namely capability and administration and bid price. Cluster Capability (CAP) consists of Financial Capability (FC), Technical Capability (TC), Previous Experience (PE), Resource (RS), HSE (Health, Safety, Security and Environment) (HS), and Current Workload (CW). Cluster Administration and Bid Price (ABP) consists of criteria Administration (AD) and Bid 
price (BP). For application, an example is given to the selection of sub-contractors for the work of PCU Girder, the Musi IV Bridge Project Palembang, which consists of 3 sub-contractors.

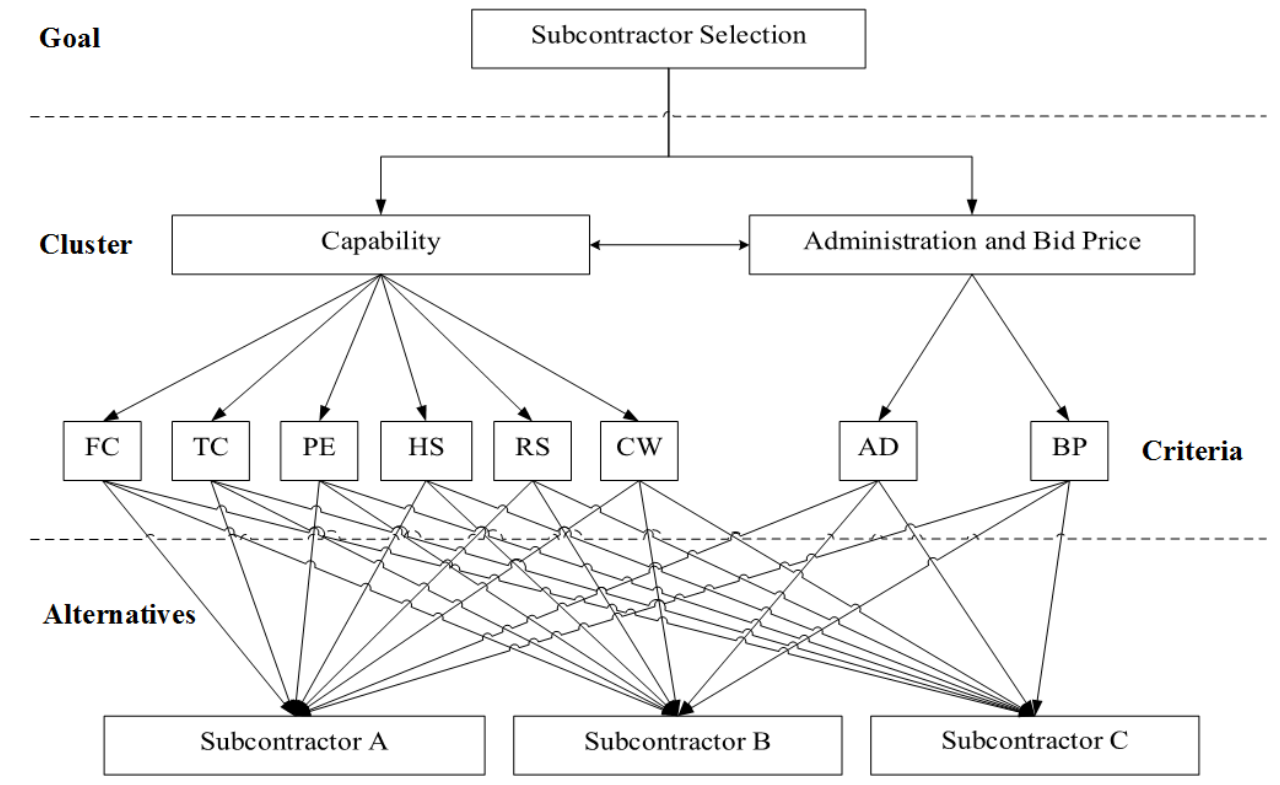

Fig. 1. Hierarchical Structure for Subcontractor Selection.

\subsection{Weight of criteria for research respondents}

The criteria weight of each respondent was obtained from the calculation of geometric mean between goal weight and pairwise comparisons. The weight of each criterion and feedback weight is obtained by Super Decisions software. The calculation results can be seen in Table 1 .

Table 1. Criteria weights for all respondent.

\begin{tabular}{|c|c|c|c|c|c|c|c|c|}
\hline \multirow{3}{*}{ Cluster } & \multirow{3}{*}{ Criteria } & \multicolumn{7}{|c|}{ Respondent } \\
\hline & & 1 & 2 & 3 & 4 & 5 & 6 & 7 \\
\hline & & Weights & Weights & Weights & Weights & Weights & Weights & Weights \\
\hline \multirow{6}{*}{ 它 } & $\mathrm{FC}$ & 0.0833 & 0.0918 & 0.0407 & 0.0829 & 0.1329 & 0.1493 & 0.1493 \\
\hline & $\mathrm{TC}$ & 0.0833 & 0.1171 & 0.1411 & 0.0829 & 0.1910 & 0.0779 & 0.0779 \\
\hline & PE & 0.0833 & 0.0985 & 0.0441 & 0.0829 & 0.0427 & 0.0650 & 0.0650 \\
\hline & RS & 0.0833 & 0.0622 & 0.1256 & 0.0943 & 0.0427 & 0.0705 & 0.0705 \\
\hline & $\mathrm{CW}$ & 0.0833 & 0.0622 & 0.1256 & 0.0783 & 0.0427 & 0.0588 & 0.0588 \\
\hline & HS & 0.0833 & 0.0622 & 0.0300 & 0.0783 & 0.0480 & 0.0463 & 0.0463 \\
\hline \multirow{2}{*}{$\frac{0}{4}$} & $\mathrm{AD}$ & 0.2500 & 0.2530 & 0.1804 & 0.2503 & 0.2500 & 0.2661 & 0.2661 \\
\hline & BP & 0.2500 & 0.2530 & 0.3124 & 0.2503 & 0.2500 & 0.2661 & 0.2661 \\
\hline
\end{tabular}

\subsection{Final Criteria Weights}

Final Criteria Weights are the weight of all criteria of the model created, so that they can be used to determine the prospective winners from the sub-contractor. To calculate the final criteria 
weight, geometric mean calculation was used for the seven respondents who were assisted by using spreadsheet program software. In Table 2 shows the recapitulation of the calculation of the final weight of the criteria and normalization in the selection of sub-contractors.

The final result of the weighting indicates that the bid price is the most weighted criterion. This indicates that this criterion is the main criterion in determining the prospective bid winner. However, this criterion is not the main thing in determining the winner because there are other criteria that have a large weight, namely administration and financial ability. This shows that the selection of prospective winners uses the basis of the bid price with consideration of other criteria such as administration, technical ability and financial capability. Consideration of other criteria will be able to anticipate or reduce the risks of sub-contractors who have poor performance.

Table 2. Final criteria weights and normalization weights.

\begin{tabular}{|c|c|c|c|}
\hline Cluster & Criteria & Final Criteria Weights & Normalization \\
\hline \multirow{6}{*}{ 㐫 } & FC & 0.0962 & 0.0992 \\
\hline & $\mathrm{TC}$ & 0.1041 & 0.1073 \\
\hline & PE & 0.0659 & 0.0680 \\
\hline & RS & 0.0748 & 0.0771 \\
\hline & $\mathrm{CW}$ & 0.0535 & 0.0551 \\
\hline & HS & 0.0691 & 0.0712 \\
\hline \multirow{2}{*}{$\frac{0}{4}$} & $\mathrm{AD}$ & 0.2434 & 0.2508 \\
\hline & $\mathrm{BP}$ & 0.2632 & 0.2713 \\
\hline
\end{tabular}

\subsection{Alternative Criteria Weight}

The calculation of alternative criteria weight aims to determine the weighting criteria of each alternative. At this time the selection of three Girder PCU sub contractors who had worked in the project of the Infrastructure Department I PT. X. The three sub-contractors include SubContractor A, Sub-Contractor B and Sub-Contractor C. Table 4 is an example of assessment of Sub-Contractor A based on the criteria used.

Table 3. Assessments for alternatives 1 (Sub-Contractor A).

\begin{tabular}{ccccccc}
\hline \multirow{2}{*}{ Subcontractor } & Criteria & $\begin{array}{c}\text { Number of } \\
\text { Aspects }\end{array}$ & Assessment & Average & Total Average & $\begin{array}{c}\text { Alternatives } \\
\text { Weights }\end{array}$ \\
\cline { 3 - 7 } & & $(\mathrm{n})$ & $(\mathrm{X} 1)$ & $\begin{array}{c}(\mathrm{Y} 1)= \\
(\mathrm{X} 1 / \mathrm{n})\end{array}$ & $(\mathrm{Z} 1)=(\mathrm{Y} 1+\mathrm{Y} 2+\mathrm{Y} 3)$ & $(\mathrm{Y} 1) /(\mathrm{Z} 1)$ \\
\hline \multirow{5}{*}{ Sub-Contractor } & FC & 4 & 20 & 5 & 15 & 0.33 \\
& AC & 5 & 50 & 10 & 22 & 0.45 \\
& RE & 1 & 10 & 10 & 20 & 0.50 \\
& CW & 4 & 40 & 10 & 25 & 0.40 \\
& HS & 2 & 10 & 10 & 30 & 0.33 \\
& AD & 3 & 20 & 10 & 27.50 & 0.36 \\
& BP & 4 & 20 & 6.67 & 16.67 & 0.40 \\
\end{tabular}

By combining the existing criteria and the results of the assessment of all sub-contractors, Sub-Contractor A is obtained as the first rank as the prospective bidder. 


\subsection{Sensitivity Analysis}

The purpose of this sensitivity analysis is to determine the output stability of the sub-contractor selection model. The analysis is carried out on each criterion used in the selection, namely the criteria of financial capability, technical ability, prior experience, resources, current workload, health, safety, security and environment, administration, and bid price. Based on the analysis, obtained the value of the sensitivity of the criteria of financial capability of (0.0263), technical ability of (0.1711), previous experience of (0.1316), HSE of (0.0264), administration of (0.2632), the bid price is $(0.2737)$, and the criteria for the resources and project load that are being implemented are insensitive.

There are criteria that have a great sensitivity, namely the offer price, administration and previous work experience. So that caution is needed in assessing sub-contractors based on these criteria so that prospective winners can be obtained accordingly.

\section{Conclusions}

From the analysis it can be concluded that the criteria for bid price (0.2713) are the criteria that have the greatest weight. This weight is not too dominant because there are other criteria that have a large enough weight that is administration (0.2508), technical ability (0.1073) and financial ability (0.0992). This shows that not only the bid price factor is the basis for determining the winning bidder, but there are other criteria that serve as the basis for determining the prospective winners. The results of the application model in the selection with the Musi IV Bridge Project case were obtained by Girder PCU sub contractor who became the prospective winner was the Sub-Contractor A.

\section{References}

[1] Y. A. Messah, D. S. Krinsnayanti, and R. D. R. Pono, "Kajian Kriteria Pemilihan Subkontraktor Oleh Kontraktor Utama Dengan Menggunakan Metode Analytic Hierarchy Process(Ahp)," J. Tek. Sipil, vol. 1, no. 3, pp. 43-56, 2012.

[2] L. Zulaihah, "Pemilihan Subkontraktor PT X Dengan Metode," Bina Tek., vol. 12, no. 1, pp. 95 $102,2016$.

[3] M. F. N. Aulady, F. T. Nuciferani, and Y. Pratama, "Pemilihan Subkontraktor pada Proyek Pengembangan Rumah Sakit Dr. Soetomo dengan Menggunakan Metode Analytical Hierarchy Process," in Seminar Nasional Sains dan Teknologi Terapan IV, 2016, p. A.93-A.98.

[4] W. Hartono, L. Nurhidayah, and Sugiyarto, "Pemilihan Rekanan Jasa Konstruksi / Kontraktor Dengan Metode Ahp ( Studi Kasus Pengadaan Di Universitas Sebelas Maret (UNS)," Matriks Tek. Sipil, vol. IV, no. 1, pp. 8-16, 2016.

[5] H. Muhendra, S. Hasibuan, and U. M. Buana, "Seleksi Sub-Kontraktor Proyek Konstruksi Jalan Layang The Sub-Contractor Selection of Fly Over Construction Project," J. Manaj. Transp. dan Logistik, vol. 05, no. 01, pp. 43-54, 2018.

[6] B. V. Mahavidyalaya, V. Vidhyanagar, and N. V. Vidhyanagar, "An Approach of Contractor Selection By Analytical Heirarchy Process," Natl. Conf. Recent Trends Eng. Technol. An, no. May, pp. 1-6, 2011.

[7] M. Almeida, "A Selection Method In Construction Project Management Using Analytic Network Process ( ANP ) As A Tool In Decision,” in DLSU Research Congress 2017 De La Salle University, Manila, Philippines, 2017, pp. 1-14. 